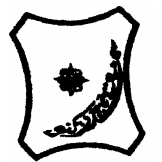

Bayero Journal of Pure and Applied Sciences, 7(1): 75 - 79

Received: February 2014

Accepted: May 2014

ISSN $2006-6996$

\title{
PROXIMATE ANALYSIS AND CONCENTRATION OF SOME HEAVY METALS IN SELECTED POULTRY FEEDS IN KANO METROPOLIS, NIGERIA
}

\author{
Bukar, $H^{1}$ and Saeed, M. D. ${ }^{2}$ \\ Department of Pure and Industrial Chemistry, Bayero University, P.M.B. 3011, Kano-Nigeria \\ hadyb20@yahoo.com
}

\begin{abstract}
Proximate analysis and some heavy metals determination were carried out in selected poultry feed samples used as starter, grower, layer and finisher which were obtained from Kano Metropolis, Nigeria. The heavy metals contents were determined using Atomic Absorption Spectroscopy and expressed in $\mathrm{mg} / \mathrm{kg}$ while the proximate composition were expressed in \%. Mean to standard deviation of the proximate composition of the feeds analyzed shows moisture content ranged from $11.33 \pm 4.48 \%-04.98 \pm 01.58 \%$, ash content $20.47 \pm 12.67 \%-09.59 \pm 2.95 \%$, lipid ranged between $06.91 \pm 01.92 \%$ to $4.14 \pm 1.90 \%$, crude protein from $24.26 \pm 04.16 \%-16.44 \pm 11.29 \%$, crude fibre $15.90 \pm 16.46 \%-03.41 \pm 00.17 \%$, carbohydrate $50.70 \pm 21.63 \%-39.67 \pm 10.68 \%$. The mean results of the heavy metals concentration ranged from $(2.26 \pm 0.67$ to $1.20 \pm 0.51) \mathrm{mg} / \mathrm{kg},(1.63 \pm 0.43$ to $1.37 \pm 0.28) \mathrm{mg} / \mathrm{kg}$ and $(0.56 \pm 0.26$ to $0.47 \pm 0.13) \mathrm{mg} / \mathrm{kg}$ for cadmium, nickel and lead respectively. $\mathrm{Ni}$ and $\mathrm{Pb}$ levels in the feeds were within the permissible limits while Cd level in all the samples exceeded the permissible limit by regulatory bodies. These results were subjected to one way analysis of variance (ANOVA) $(p<0.05)$.
\end{abstract}

Keywords: Proximate composition; Heavy metals; Poultry feed; AAS,

\section{INTRODUCTION}

Poultry is a category of domesticated birds kept by humans for the purpose of collecting their eggs, or killing for their meat and/or feathers. Poultry is the second most widely eaten meat in the world, accounting for about $30 \%$ of meat production worldwide, after beef at 38\% (Raloff, 2003). Poultry is basically a source of economic, palatable and healthy food protein (Mahesar et al., 2010). Poultry feed is food for farm poultry, including chickens, ducks, geese and other domestic birds. Feed for poultry mostly consists of grains (Mark, 2008). The feed consist of grains such as corn, wheat or barley, oil seeds, cake meal (originating mainly from oil producing seeds such as soybeans) sunflower seeds, peanuts, cotton seed and protein products of animal origin such as fish meal, meat and bone meal (Bale et al., 2002). Poultry feeds are known as a complete feed, since it is prepared in such a way to contain all the vitamins, minerals, energy, protein and other nutrients essential for proper health of the birds, egg production and growth. Poultry farming is now one of the most important agricultural sectors in the world. It is expanding rapidly as an industry. Most of the commercial poultry farmers depend on commercial feeds for their stock. The role of these poultries is to meet up with the increasing demand for meats and eggs as protein. Dick (2002) suggested that harmonization of feed qualities can only be possible when a given standard is adopted nationwide. Nowadays, it has been noted that some of the commercial feeds producers failed to meet up with standards for the requirement of poultry and in many ways, the source of raw material for the production of the feeds tends to be contaminated with heavy metals. Heavy metals, which are defined as metals with specific gravity of more than $5 \mathrm{~g} / \mathrm{cm}^{3}$, are serious threat human because of their toxicity, bioaccumulation and biomagnifications in food chain (Demirezen and Uruc, 2006). Although contamination of animal feeds by toxic metals cannot be entirely avoided given the prevalence of these pollutants in the environment, there is need for such contamination to be minimized, with the aim of reducing both direct effects on animal health and indirect effects on human health (SCAN 2003). Some mineral elements such iron, manganese, copper and zinc are essential dietary nutrients for poultry and livestock. However, all mineral elements can have an adverse effect upon human and animals at excessively high or low concentration if included in the diet (Okoye et al., 2011). The aim of this study is to determine the proximate composition and concentration of some heavy metals in selected poultry feeds in Kano Metropolis, Nigeria.

\section{Sampling}

Four different poultry feeds (Animal care, Hybrid, Niger, and Sovet coded as A, B, C and D respectively) commercially available in Kano metropolis were purchased from different locations within the metropolis.

\section{Materials and method}

All plastic and glass wares used were washed with detergent and rinsed with water before immersion in $10 \%$ nitric acid solution. They were finally rinsed with deionized water. Analar grade reagents and deionized water were used throughout the analysis.

Proximate Analysis

Samples were subject to proximate analysis in accordance with standard methods described by AOAC (2005). 


\section{Moisture Content Determination}

This was done based on the difference between the net weight and the weight after drying to a constant weight. A clean dried petri-dish was weighed $\left(\mathrm{W}_{1}\right)$ and $3 \mathrm{~g}$ of the samples were placed on it, and then weighed $\left(\mathrm{W}_{2}\right)$. This was then placed in an oven at $120^{\circ} \mathrm{C}$ for 3hrs. The dish was removed and cooled in a desiccator for $30 \mathrm{mins}$ and finally weighed $\left(\mathrm{W}_{3}\right)$ AOAC (2005).

\section{Total Ash Determination}

A crucible was dried in an oven for $24 \mathrm{hrs}$, cooled and weighed $\left(W_{1}\right)$. The dried sample weighed $2 g\left(W_{2}\right)$ was placed in a crucible and subjected to ashing in a muffle furnace at constant temperature of $550^{\circ} \mathrm{C}$ until a constant final weight for the ash was obtained. After ashing, the ash was covered with a lid and placed in desiccator prior to weighing. This was then measured as $\mathrm{W}_{3}$ AOAC (2005).

\section{Lipid Content Determination}

A quantity of the sample $(3 \mathrm{~g})$ was weighed and folded in a filter paper. It's then placed in extraction thimble and cotton wools placed on top. The whole apparatus was then connected after the addition of about $300 \mathrm{~cm}^{3}$ of $60^{\circ}-80^{\circ} \mathrm{C}$ petroleum ether into the weighed extraction flask. The extraction was then carried out for 3hrs using a heating mantle and making sure there was continuous flow of water in the condenser. The sample was then removed, air-dried and then placed in an oven at $80^{\circ} \mathrm{C}$ until a constant weight was obtained. The extractible lipid was then calculated as percentage lipid (\%) AOAC (2005).

\section{Crude Protein}

Dried sample $(0.15 \mathrm{~g})$ was weighed and the content was transferred into the kjeldahl digestion flask (capacity $\left.30-35 \mathrm{~cm}^{3}\right)$. Catalyst $0.8 \mathrm{~g} \quad(0.7 \mathrm{~g}$ sodium sulphate, $0.06 \mathrm{~g}$ copper sulphate, and $0.04 \mathrm{~g}$ mercury (II) oxide red) was added into the digestion flask; $2 \mathrm{~cm}^{3}$ of conc. $\mathrm{H}_{2} \mathrm{SO}_{4}$ was also added. The mixture was heated on a heating mantle at an inclined position for $1 \mathrm{hr}$ until the liquid became clear. The digest was cooled and made alkaline with $15 \mathrm{~cm}^{3}$ of $40 \% \mathrm{w} / \mathrm{v}$ $\mathrm{NaOH}$. The digest was then transferred to the steamed out apparatus. The ammonia steam distilled into $10 \mathrm{~cm}^{3}$ of $2 \%$ boric acid solution with 5 drops of methyl red indicator for $15 \mathrm{mins}$. The distilled ammonia was then titrated with $0.02 \mathrm{M} \mathrm{HCl} \mathrm{AOAC} \mathrm{(2005).}$

Table 1: Percentage of moisture in the feed samples

\begin{tabular}{lllll}
\hline Sample & A & B & C & D \\
\hline Starter & 04.17 & 08.00 & 07.40 & 15.00 \\
Grower & 03.81 & 09.60 & 08.59 & 15.00 \\
Layer & 07.29 & 08.80 & 07.92 & 09.40 \\
Finisher & 04.65 & 07.83 & 07.50 & 05.90 \\
Mean & 04.98 & 08.56 & 07.85 & 11.33 \\
S.D & 01.58 & 00.81 & 00.54 & 04.48 \\
& & & & \\
\hline
\end{tabular}

\section{Crude fiber}

The crude fibre was determined by subjecting $3 \mathrm{~g}$ of the residual powered sample from moisture analysis and ether extraction to successive treatments with boiling $200 \mathrm{~cm}^{3}$ of $0.1275 \mathrm{M} \mathrm{H}_{2} \mathrm{SO}_{4}$ acid under reflux for 30 mins, washed several times with hot water until it is acid free. The residue was again subjected to the same treatment using $200 \mathrm{~cm}^{3}$ of $0.313 \mathrm{M} \mathrm{NaOH}$ solution, washed thoroughly with hot water until it was base free. It was then dried to a constant weigh in an oven at $100^{\circ} \mathrm{C}$, cooled in a desiccator and weighed. The weighed sample was incinerated in a muffle furnace at $550^{\circ} \mathrm{C}$ for $2 \mathrm{hrs}$ until a constant weight was obtained. The crude fibre was calculated as the loss in weight on ashing AOAC (2005).

\section{Carbohydrate Content Determination}

Total carbohydrate was determined by difference:

Carbohydrate $=[100-($ crude protein + crude fibre + lipid + moisture + ash)]. (Akubor et al., 2000)

\section{Sample digestion for heavy metals}

Samples $2.0 \mathrm{~g}$ each were weighed in a crucibles using $\mathrm{H} 30$ Mettler Balance. Conc. nitric acid $1 \mathrm{~cm}^{3}$ was added as ashing aid and then pre-ashed by placing the crucible on a heater until the content charred. The pre-ashed samples were then transferred into a muffle furnace at a temperature of $550^{\circ} \mathrm{C}$ for $3 \mathrm{hrs}$ after which they were allowed to cool. The samples were then dissolved using $5 \mathrm{~cm}^{3}$ of $30 \% \mathrm{HCl}$ and then filtered using Whatman filter papers. The filtrates were individually poured into $50 \mathrm{~cm}^{3}$ standard flask and made-up to mark with deionized water. The samples solutions were then kept in sample bottles for further analysis using Atomic Absorption Spectroscopy (Okoye et al., 2011).

\section{Statistical Analysis}

Data collected were subjected to one way analysis of variance (ANOVA) $(p<0.05)$ to assess whether they varied significantly between the feeds. All statistical calculations were performed with excel window 2007.

\section{RESULTS AND DISCUSSION}

The results of the analysis are presented in $1-6$ below. The results indicated proximate composition of the various poultry feeds. 
Table 2: Percentage of Ash content in the feed samples

\begin{tabular}{lllll}
\hline Sample & A & B & C & D \\
\hline Starter & 12.24 & 14.99 & 13.42 & 09.33 \\
Grower & 07.24 & 14.93 & 12.29 & 38.65 \\
Layer & 12.03 & 18.54 & 14.06 & 15.90 \\
Finisher & 06.84 & 16.00 & 11.34 & 17.99 \\
Mean & 09.59 & 16.12 & 12.78 & 20.47 \\
S.D & 02.95 & 01.69 & 01.21 & 12.67 \\
\hline
\end{tabular}

Where $A=$ Animal care, $B=$ Hybrid,$C=$ Niger, $D=$ Sovet

Table 3: Percentage of Lipid in the feed samples

\begin{tabular}{lllll}
\hline Sample & A & B & C & D \\
\hline Starter & 06.87 & 06.28 & 04.56 & 05.98 \\
Grower & 06.97 & 09.20 & 06.60 & 01.47 \\
Layer & 03.07 & 04.66 & 06.50 & 04.57 \\
Finisher & 06.60 & 07.48 & 05.20 & 04.55 \\
Mean & 05.88 & 06.91 & 05.72 & 04.14 \\
S.D & 01.88 & 01.92 & 01.00 & 01.90 \\
\hline
\end{tabular}

Table 4: Percentage of Crude protein in the feed samples

\begin{tabular}{lllll}
\hline Sample & A & B & C & D \\
\hline Starter & 17.50 & 17.00 & 23.56 & 15.16 \\
Grower & 09.30 & 32.20 & 19.80 & 16.30 \\
Layer & 09.36 & 08.86 & 23.80 & 26.80 \\
Finisher & 14.46 & 07.70 & 29.86 & 25.66 \\
Mean & 12.66 & 16.44 & 24.26 & 20.98 \\
S.D & 04.04 & 11.29 & 04.16 & 06.09 \\
\hline
\end{tabular}

Where $\mathrm{A}=$ Animal care, $\mathrm{B}=$ Hybrid, $\mathrm{C}=$ Niger, $\mathrm{D}=$ Sovet

Table 5: Percentage of crude fiber in the feed samples

\begin{tabular}{lllll}
\hline Sample & A & B & C & D \\
\hline Starter & 38.75 & 03.65 & 04.05 & 03.66 \\
Grower & 03.67 & 11.59 & 03.67 & 03.33 \\
Layer & 17.12 & 04.00 & 02.99 & 03.36 \\
Finisher & 04.07 & 03.60 & 03.03 & 03.30 \\
Mean & 15.90 & 05.71 & 03.44 & 03.41 \\
S.D & 16.46 & 03.92 & 00.52 & 00.17 \\
\hline
\end{tabular}

Table 6: Percentage of Carbohydrate in the feed samples

\begin{tabular}{lllll}
\hline Sample & A & B & C & D \\
\hline Starter & 20.47 & 50.08 & 47.01 & 50.87 \\
Grower & 68.83 & 22.48 & 49.05 & 25.25 \\
Layer & 50.13 & 55.14 & 44.73 & 39.97 \\
Finisher & 63.38 & 57.39 & 43.07 & 42.60 \\
Mean & 50.70 & 46.27 & 45.97 & 39.67 \\
S.D & 21.63 & 16.15 & 02.62 & 10.68 \\
\hline
\end{tabular}

Where $A=$ Animal care, $B=$ Hybrid, $C=$ Niger, $D=$ Sovet

The moisture content ranges from $3.81-7.29 \%, 7.83-$ $9.60 \%, 7.40-8.59 \%$ and $5.90-15.00 \%$ for feed $(A, B$, $C \& D)$, respectively. Where Feed $A$ was observed to have the least moisture content in grower (3.81\%). There was significant difference observed in the moisture content of the entire feeds sample $(p<0.05)$. Ash content of a poultry feeds relates to the inorganic mineral content. The ash content found in feeds $(A, B$,
C \& D) are in the range of $6.84-12.24 \%, 14.93-$ $18.54 \%$, $11.34-14.06 \%$ and $9.33-38.65 \%$ respectively. Lipid in poultry diets is often incorporated to enhance the energy levels. The lipid content in the feed were detected in the range of $3.07-6.97 \%, 4.66-$ $9.20 \%, 4.56-6.60 \%$ and $1.47-5.98 \%$ for feed A, B, C and $D$, respectively. The lipid content in all the feeds is low with the least in starter $(1.47 \%)$. 
Crude protein is one of the most important nutrients to quantify in a prospective feed due to the fact that it is one of the most costly to supply and deficiency of protein has a drastic effect on growth and production (Mahesar et al., 2010). Crude protein were found in the range of $9.30-17.50 \%, 7.70-32.20 \%, 19.80-$ $29.86 \%$ and $15.16-26.80 \%$ respectively for feeds $A, B$, $C$ and D. Finisher shows the least in crude protein (7.70\%).

Crude fiber content of the feeds were in the ranges of 4.07-38.75\%, 3.60-11.59\%, 2.99-4.05\%, and 3.30$3.66 \%$, for feed A, B, C and D, respectively. However, Feed $C$ showed the least crude fiber in layer $(2.99 \%)$ whereas feed A starter was found to have the highest with $38.75 \%$.
Generally, the carbohydrate which is also referring to nitrogen free extract is high in all the feeds. Carbohydrates are essential source of energy. Carbohydrate content were in the range of 20.47$68.83 \%$, 22.48-57.39\%, 43.07-49.05\%, 25.25$50.87 \%$ for feed A, B, C and D respectively. Carbohydrate was found to be lowest in feed $B$ grower with $22.48 \%$.

\section{Heavy Metals}

Tables 7-10 below show the results of the heavy metal concentration in $\mathrm{mg} / \mathrm{kg}$ with the mean, and standard deviation for the various feeds. Where $A=$ Animal care $B=$ Hybrid,$C=$ Niger $D=$ Sovet

Table 7: Heavy metals concentration of feed A in $\mathbf{~ m g} / \mathbf{k g}$

\begin{tabular}{llllll}
\hline Sample & Starter & Grower & Layer & Finisher & Mean \pm S.D \\
\hline $\mathrm{Cd}$ & 2.13 & 1.60 & 1.60 & 2.13 & $1.86 \pm 0.31$ \\
$\mathrm{Ni}$ & 1.37 & 1.37 & 1.71 & 2.06 & $1.63 \pm 0.33$ \\
$\mathrm{~Pb}$ & 0.27 & 0.80 & 0.53 & 0.27 & $0.47 \pm 0.26$ \\
\hline
\end{tabular}

Table 8: Heavy metals concentration of feed B in $\mathbf{~ m g} / \mathbf{k g}$

\begin{tabular}{llllll}
\hline Sample & Starter & Grower & Layer & Finisher & Mean \pm S.D \\
\hline $\mathrm{Cd}$ & 1.60 & 2.13 & 3.19 & 2.13 & $2.26 \pm 0.67$ \\
$\mathrm{Ni}$ & 1.37 & 1.37 & 1.71 & 1.03 & $1.37 \pm 0.28$ \\
$\mathrm{~Pb}$ & 0.53 & 0.80 & 0.80 & 0.27 & $0.56 \pm 0.26$ \\
\hline
\end{tabular}

Table 9: Heavy metals concentration of feed $\mathrm{C}$ in $\mathrm{mg} / \mathbf{k g}$

\begin{tabular}{llllll}
\hline Sample & Starter & Grower & Layer & Finisher & Mean \pm S.D \\
\hline $\mathrm{Cd}$ & 1.06 & 0.53 & 1.60 & 1.60 & $1.20 \pm 0.51$ \\
$\mathrm{Ni}$ & 1.03 & 1.71 & 1.03 & 1.71 & $1.37 \pm 0.40$ \\
$\mathrm{~Pb}$ & 0.53 & 0.80 & 0.53 & 0.27 & $0.53 \pm 0.22$ \\
\hline
\end{tabular}

Table 10: Heavy metals concentration of feed D in $\mathbf{~ m g} / \mathbf{k g}$

\begin{tabular}{llllll}
\hline Sample & Starter & Grower & Layer & Finisher & Mean \pm S.D \\
\hline $\mathrm{Cd}$ & 1.06 & 2.13 & 1.60 & 2.67 & $1.86 \pm 0.69$ \\
$\mathrm{Ni}$ & 1.71 & 1.03 & 1.71 & 2.06 & $1.63 \pm 0.43$ \\
$\mathrm{~Pb}$ & 0.53 & 0.53 & 0.53 & 0.27 & $0.47 \pm 0.13$ \\
\hline
\end{tabular}

Where $\mathrm{A}=$ Animal care, $\mathrm{B}=$ Hybrid, $\mathrm{C}=$ Niger $\mathrm{D}=$ Sovet

Table 7 shows the concentration of the heavy metals in feed $A$ with ranged from $0.27-2.13 \mathrm{mg} / \mathrm{kg}$. In feed $A$, lead has the lowest concentration of heavy metal with $0.27 \mathrm{mk} / \mathrm{kg}$ in both starter and finisher. Table 8 shows concentration level of the heavy metals in feed b. The concentration ranged from $0.27-319 \mathrm{mg} / \mathrm{kg}$ where cadmium has the highest concentration of $3.19 \mathrm{mg} / \mathrm{kg}$ in layer feed. Table 9 shows the concentration of the heavy metals in feed $\mathrm{C}$ with ranged from $0.27-1.71 \mathrm{mg} / \mathrm{kg}$. In this feed, nickel has the highest concentration in grower and finisher while lead has the lowest in finisher feed. Table 10 above shows the concentration of heavy metals in feed $D$. The concentration of the heavy metals ranged from $0.27-2.67 \mathrm{mg} / \mathrm{kg}$, where finisher feed has the highest concentration of $2.67 \mathrm{mg} / \mathrm{kg}$.

In general, poultry feed reference standard prepared by the Standard Organization of Nigeria (SON), there are requirements of some heavy metals mentioned as micro-nutrient but no standard as a contaminant in terms of maximum acceptable limit for the heavy metals was mentioned. Cadmium levels were found in all samples to exceed the permissible limit FAO/WHO $(1 \mathrm{mg} / \mathrm{kg})$, except for feed $\mathrm{C}$ grower which was found to be within the limit with $(0.532 \mathrm{mg} / \mathrm{kg})$. Nickel level was detected in the feed but all were found to be within the maximum acceptance limit of $4.05 \mathrm{mg} / \mathrm{kg}$ of the Act No. 21, NRC (2006). Lead concentrations in all the samples were within the permissible limit of $5 \mathrm{mg} / \mathrm{kg}$ set by $\mathrm{FAO} / \mathrm{WHO}$. The results for lead obtained in this study were lower than 1.10$7.85 \mathrm{mg} / \mathrm{kg}$ and $23.2-32.6 \mathrm{mg} / \mathrm{kg}$ obtained by Okeoye et al., (2011) and Mahesar (2011) in their analysis of poultry feeds respectively.

\section{CONCLUSION}

In conclusion, data obtained in the proximate analysis represent a great variation among the quality of the poultry feeds from selected manufacturers. Nickel and lead were found to be within the maximum acceptable limits set by regulatory bodies. 
However, Cadmium concentration was found to exceed the maximum acceptable limit with the exception of feed $\mathrm{C}$ grower. This makes the feeds contaminated with Cadmium and not safe for poultry consumption since heavy metals are bio-accumulative

\section{REFERENCES}

Akubor, P.I., Isolokwu, P.C., Ugbane, O., Onimawo, I.A (2000). Proximate composition and functional properties of African bread kernel and flour blends. Food Research International 33, 707-712.

A.O.A.C. (2005): Official Methods of Analysis $18^{\text {th }}$ edition, Association of Official Analytical Chemist, Washington D. C. U.S.A

Bale, O.O., Sekoni, A.A. and Kwanashine, C. N. (2002). A case study of possible health hazard associated with poultry house. Nig. J. Anim. Prod., 29:1022-1111.

Demirezen, D. and Uruc, K. (2006). Comparative study of trace elements in certain fish, meat and meat products. Meat sci., 74:255-260.

Dick, Z. (2002). Safe feed with the Codex Alimentations. Feed Tech, p 619.

Mahesar, S.A, Sherazi S.T.H, Abdul Niaz, M.I, Bhanger, S.A. (2010). Simultaneous assessment of zinc, cadmium, lead and copper in poultry feeds by differential pulse anodic striping voltammetry. Food and Chemical Toxicology, doi: 10.1016/j.fct.2010.05.071. and have the tendency to be transferred to human after consumption. Therefore extra care needs to be carried out by manufacturers in order to reduce the heavy metals in the feeds to the permissible levels.

Mark, P (2008). Poultry Disease 6edition, Elsevier Health Sciences. P550 ISBN 978-0-2862-5. Retrieved 7 November 2012.

Nazri, M.M. (2003). Development of poultry industry. Economic review. Available online at: Nazri, M.M.. "Development of poultry industry", Economic Review, March 2003 Issue.

Okoye, C.O.B, Ibeto, C.N and Ihedioha, J.N (2011). Assessment of heavy metals in chicken feeds sold in south eastern, Nigeria. Advance in Applied science Research, 2(3):63-68.

Raloff, J (2003). Food for thought: Global food trends. Science News Online. May 31, 2003.

Santhi, D., V. Balakrishan, A. Kalaikannan and K.T. Radhakrishnan, 2008. Presence of heavy metals in pork products in Chennai (India). Am J. food Technol., 3(3):192-199.

SCAN, 2003: Scientific Committee on animal Nutrition: Opinion of the undesirable substance in feed. Retrieved from: http:/Europe.eu.int/comm./food/fs/sc/scan/o ut 126_bis_en.pdf, (Accessed on: 25April, 2003). 